\title{
Human lung tumours may coexpress different classes of intermediate filaments
}

\author{
K C GATTER, M S DUNNILL, G N P VAN MUIJEN,* D Y MASON \\ From the Nuffield Department of Pathology, John Radcliffe Hospital, Oxford, and the *Department of \\ Pathology, University Medical Centre, Leiden, The Netherlands
}

SUMMARY Ninety four pulmonary neoplasms were examined immunocytochemically with two or three different monoclonal antibodies against the intermediate filament proteins cytokeratin, neurofilament, vimentin, and desmin. In normal tissues these have a different and non-overlapping distribution, and it is generally believed that tumours maintain the same pattern of expression as the tissues from which they arise. In this report, however, the coexpression of at least two (and less commonly three or four) different intermediate filaments was seen in $40 \%$ (37 of 94) of the cases of lung cancer. These results, especially if confirmed in other common types of human malignancy, have considerable implications for the use of anti-intermediate filament antibodies in diagnostic pathology.

The cytoskeleton of mammalian cells contains a meshwork of intermediate filament proteins whose biochemistry and tissue distribution have been subjects of considerable interest in recent years. Intermediate filaments can be classified into five subtypes-namely, cytokeratin, vimetin, desmin, neurofilament, and glial fibrillary acid protein (GFAP). They show different and generally nonoverlapping patterns of tissue distribution.

From a clinical point of view the differences in distribution between the individual intermediate filament classes are of particular interest: it is generally believed that tumours contain intermediate filaments of the same type of tissue from which the neoplasm has arisen (table 1). This offers a valuable means of identifying the origin of human malignancies by immunocytochemical labelling, using antibodies specific for the different classes of intermediate filament. ${ }^{1-6}$

The reliability of intermediate filaments as markers of tumour cell origin would be seriously weakened if it were shown that neoplastic transformation was accompanied by a tendency to express "inappropriate" classes of intermediate filaments. A few examples of such aberrant coexpression have been reported, notably for cytokeratin and vimentin..$^{7-12}$ This is generally thought to be a rare phenomenon and the fidelity with which the intermediate filament profiles of neoplastic cells reflect their tissue of origin has not been seriously questioned.

In this paper we report an immunocytochemicap analysis of a large series of surgical resected lung tumours in which it was shown that cases expressing two and sometimes more classes of intermediate filament were found relatively often. This suggests that the acquisition of new classes of intermediate filaments by neoplastic cells may be a more common event than has previously been thought and prompts a reassessment of the diagnostic application of antiintermediate filament antibodies.

\section{Material and methods}

LUNG SPECIMENS

Ninety four pulmonary tumours were received as lung resection specimens fresh from the operating theatre. Portions were taken for histology, electron microscopy, and immunocytochemistry and dealt

Table 1 Expression of intermediate filament proteins in normal cell types

\begin{tabular}{ll}
\hline Cytokeratin & $\begin{array}{c}\text { Keratinising and non-keratinising } \\
\text { epithelium } \\
\text { Most mesenchymal tissues and cells such as } \\
\text { fibrous tissue, cartilage, haemopoietic, } \\
\text { endothelium, melanocytes, etc } \\
\text { Vimentin }\end{array}$ \\
$\begin{array}{l}\text { Most neurons in peripheral and central } \\
\text { nervous tissue } \\
\text { Neurofilaments }\end{array}$ & $\begin{array}{l}\text { Skeletal, cardiac, and smooth muscle } \\
\text { Astrocytes }\end{array}$ \\
Desmin & GFAP
\end{tabular}


Table 2 Summary of immunocytochemical labelling of lung tumours with monoclonal antibodies against different classes of intermediate filaments

\begin{tabular}{llllll}
\hline Tumour type & No of cases & Cytokeratin & Neurofilament & Vimentin & Desmin \\
\hline Squamous cell & & & & 12 & 18 \\
$\quad$ carcinoma & 60 & 60 & 1 & 4 & 4 \\
Adenocarcinoma & 17 & 17 & 2 & 6 & 0 \\
Small cell carcinoma & 9 & 8 & 21 & 3 & 1 \\
Carcinoid & 8 & 94 & & 27 & 6 \\
Total & 94 & &
\end{tabular}

Table 3 Monoclonal antibodies used for study of intermediate filament expression by human lung tumours

\begin{tabular}{|c|c|c|}
\hline $\begin{array}{l}\text { Intermediate } \\
\text { flament }\end{array}$ & $\begin{array}{l}\text { Monoclonal } \\
\text { antibody }\end{array}$ & $\begin{array}{l}\text { Source or } \\
\text { reference }\end{array}$ \\
\hline \multirow[t]{2}{*}{ Cytokeratin } & \multirow{3}{*}{$\begin{array}{l}\text { LP34 } \\
\text { KL1 } \\
\text { CAM 5·2 } \\
\text { NR4 } \\
\text { MNF (2F11) }\end{array}$} & Dako \\
\hline & & Becton-Dickinson \\
\hline Neurofilaments & & $\begin{array}{l}\text { Dako } \\
\text { Eurodiagnostics }\end{array}$ \\
\hline Vimentin & $\begin{array}{l}\text { V9 } \\
\text { MVI (Vg) }\end{array}$ & $\begin{array}{l}\text { Dako } \\
\text { Eurodiagnostics }{ }^{20}\end{array}$ \\
\hline Desmin & $\begin{array}{l}\text { DE-R-11 } \\
\text { D33 }\end{array}$ & $\begin{array}{l}\text { Dako } \\
\text { van Muijen (unpublished } \\
\text { observations) }\end{array}$ \\
\hline & MDE & Eurodiagnostics \\
\hline
\end{tabular}

Antibodies recognising GFAP were not included in this study.

with as described previously. ${ }^{13}$ The tumours were categorised independently according to the WHO classification system ${ }^{14}$ by two of the authors (KCG and MSD) (table 2).

\section{IMMUNOCYTOCHEMISTRY}

Table 3 shows details of the monoclonal antibodies used in this study. Monoclonal antibodies recognising GFAP were not included in this study as those antibodies available to us in our preliminary studies showed a wide range of cross reactivity with normal epithelial tissues. For practical diagnostic purposes, antibodies against GFAP would also not normally be part of a panel for the assessment of lung tumours in man.

Cryostat sections were stained either by a three stage immunoperoxidase procedure or by the APAAP immunoalkaline phosphatase technique, as detailed previously. ${ }^{1617}$

\section{Results}

Tables 2 and 4 summarise the results of immunostaining 94 lung tumours. All of the tumours were positively labelled, usually homogeneously, for cytokeratins. In addition, however, about $40 \%$ of the tumours (37 of 94) also reacted with monoclonal antibodies against at least one other class of intermediate filament. Neurofilaments were coexpressed by 21 lung tumours $(22 \%)$, vimentin by 27 tumours $(28 \%)$, and desmin by six tumours $(6 \%)$. Fourteen tumours showed staining for three different intermediate filaments, and one small cell carcinoma was positive for all four (detected with two or three different antibodies for each intermediate filament) (figure).

In most cases the labelling for intermediate filaments other than cytokeratin was focal or patchy (in contrast to the homogeneous pattern of cytokeratin labelling) and was observed with all of the monoclonal antibodies specific for a particular class of intermediate filament. There were a few cases, however, in which focal positivity (especially for neuro-

Table 4 Details of staining patterns seen in human lung tumours coexpressing different classes of intermediate filaments

\begin{tabular}{|c|c|c|c|c|c|}
\hline Tumour type & No of cases & Cytokeratin & Neurofilament & Vimentin & Desmin \\
\hline $\begin{array}{l}\text { Squamous cell } \\
\text { carcinoma }\end{array}$ & $\begin{array}{r}10 \\
7 \\
4 \\
2 \\
1\end{array}$ & $\begin{array}{l}+ \\
+ \\
+ \\
+ \\
+\end{array}$ & $\begin{array}{l}- \\
+ \\
+ \\
- \\
+\end{array}$ & $\begin{array}{l}+ \\
+ \\
+ \\
+\end{array}$ & $\begin{array}{l}- \\
\bar{t} \\
+ \\
+\end{array}$ \\
\hline Adenocarcinoma & $\begin{array}{l}3 \\
1\end{array}$ & $\begin{array}{l}+ \\
+\end{array}$ & $\frac{-}{+}$ & $\begin{array}{l}+ \\
+\end{array}$ & - \\
\hline Small cell carcinoma & $\begin{array}{l}1 \\
1 \\
1\end{array}$ & $\begin{array}{l}+ \\
+ \\
+\end{array}$ & $\begin{array}{l}+ \\
+\end{array}$ & $\begin{array}{l}+ \\
+ \\
-\end{array}$ & $\begin{array}{l}+ \\
-\end{array}$ \\
\hline Carcinoid tumour & $\begin{array}{l}3 \\
3\end{array}$ & + & $\begin{array}{l}+ \\
+\end{array}$ & \pm & - \\
\hline
\end{tabular}



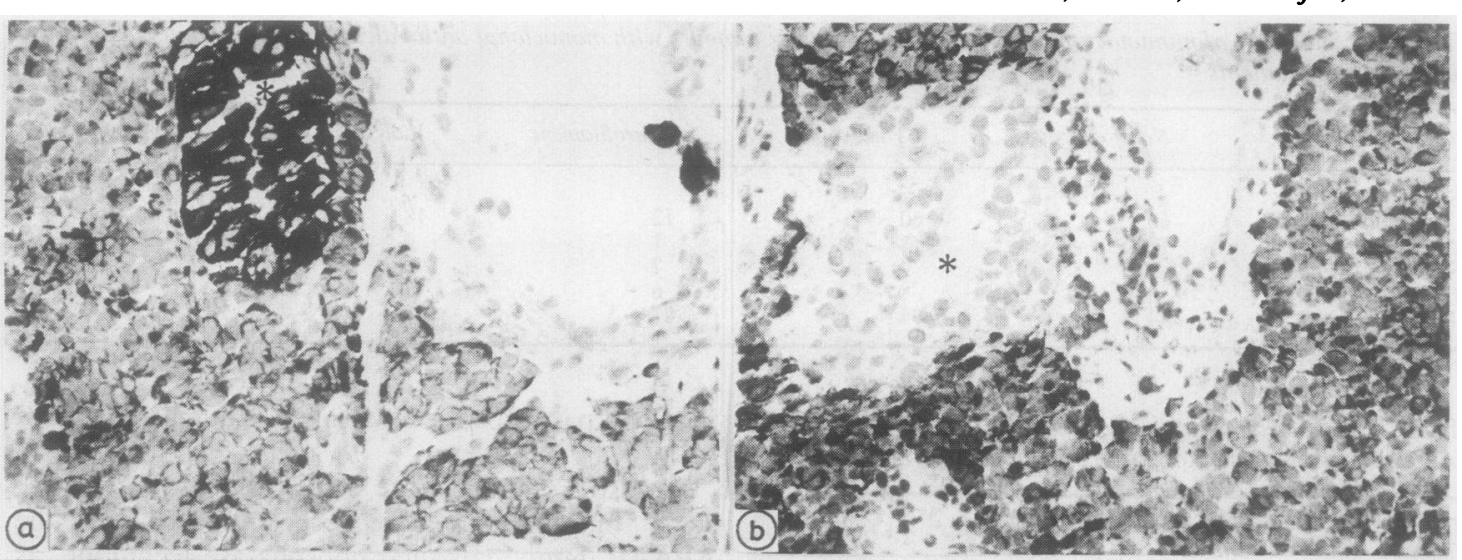

Gatter, Dunnill, van Muijen, Mason
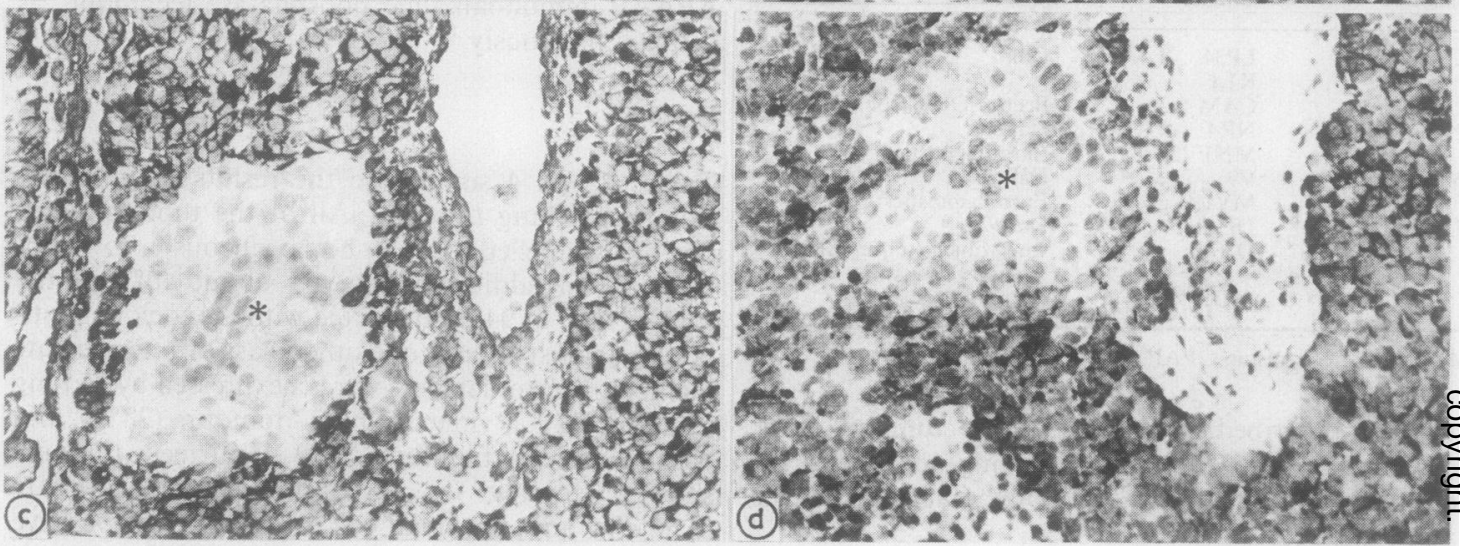

Figure Small cell carcinoma of lung expressing four different intermediate filaments: (a) cytokeratin; (b) neurofilament; (c) vimentin; and (d) desmin. Note entrapped bronchial mucosal gland (asterisk) showing typical epithelial pattern of intermediate filament expression.

filaments) was seen with only one or two of the antibodies specific for a particular intermediate filament.

\section{Discussion}

In recent years intermediate filaments have become the subject of intense research by cell biologists and pathologists. Initial studies suggested that there were no exceptions to the rule that epithelium expressed only cytokeratins, nerves only neurofilaments, etc (table 1). More recently there have been reports that vimentin is coexpressed with cytokeratins during embryonic development, in tumour cells growing in vitro, or in serous effusions, ${ }^{18-20}$ and in human myocardium and myometrium. ${ }^{21}$ It has also become clear that some tumours such as renal cell carcinomas, ${ }^{8}$ salivary tumours, ${ }^{9}$ mesotheliomas, ${ }^{12}$ and thyroid tumours ${ }^{11}$ also commonly express vimentin as well as cytokeratin. Desmin or glial filaments may also be coexpressed with vimentin in some sarcomas. ${ }^{722} 23$

The existence of exceptions such as those cited above has led to a modification of the original simple concept that any individual tumour will only express a single class of intermediate filament, characteristic of its tissue of origin. This revised view has not caused pathologists to abandon the use of intermediate filaments for tumour classification, as it is generally held that such exceptions are rare. Furthermore, it has been stated that when more than one intermediate filament is found in a human cell, one of the members of the pair will always be vimentin. ${ }^{4}$ This empirical rule was barely formulated before it too was found to be subject to exceptions, notably among neuroendocrine tumours, as Merkel cell tumours, ${ }^{24} 25$ islet cell tumours, ${ }^{26}$ parathyroid adenomas, ${ }^{27}$ and bronchial carcinoid tumours ${ }^{28}$ may coexpress neurofilaments and cytokeratins. The rarity of such exceptions was generally considered to pose little practical obstacle to the use of intermediate filaments as markers of tumour histogenesis.

This report indicates that the coexpression of at least two (and less commonly three or four) different 
classes of intermediate filaments, far from being a rare phenomenon, is often observed in one of the commonest types of malignancy in man-lung cancer. The fact that this observation has been overlooked in the past may be attributed to several factors. The material in the present series was subject to careful microscopic scrutiny, so that focal areas of aberrant intermediate filament expression, which could escape detection on more cursory examination, were detected. The use of immunoenzymatic staining techniques (rather than immunofluorescence labelling) made it possible to establish with certainty that aberrant intermediate filaments were present in the tumour cells themselves (and not within nonneoplastic cells).

There is a further element, albeit difficult to assess, accounting for the failure of previous studies ${ }^{2934}$ to detect such a high incidence of aberrant intermediate filament expression in lung tumours. A natural reluctance to destroy a beautiful hypothesis may have biased pathologists against recording unexpected immunocytochemical reactions as specific. Our initial response in the early stages of this study was also to seek alternative technical explanations for such findings, such as the detection of shared epitopes between different classes of intermediate filaments by certain monoclonal antibodies. The fact that most of the reactions in the present study, however, were confirmed using two or three unrelated monoclonal antibodies for each intermediate filament class (a control not found in previous studies) led us to abandon such an explanation.

It may be added that epitope sharing between different classes of intermediate filament cannot be excluded as an explanation of our findings, although there are theoretical grounds for thinking this unlikely (as there is no evidence of multiple genes coding for each intermediate filament other than cytokeratin). Even were such an explanation valid, it would not affect the practical implications of this report, which are concerned with the application of monoclonal antibodies against intermediate filaments for tumour classification and diagnosis.

Perhaps lung tumours are exceptional among human neoplasms in their tendency to express multiple intermediate filament types, although we have already seen similar examples of intermediate filament coexpression in smaller groups of thyroid tumours, small cell tumours of childhood, meningiomas, and different types of sarcoma. We are systematically studying other human tumours received in this department to establish whether or not the present findings are representative of a wider range of neoplasms.

The purpose of this report is not to condemn the use of antibodies to intermediate filaments in pathol- ogy. On the contrary, we and others have found them extremely valuable in several difficult areas of diagnosis-for example, anaplastic tumours, ${ }^{35} 37$ metastases in bone marrow, ${ }^{38}$ or lymph nodes. ${ }^{39}$ They should, however, be used in conjunction with other reagents, such as antileucocyte common antigen, S100 protein, or epithelial membrane antigen. The dream of a panel of anti-intermediate filament antibodies solving all the problem areas of histopathology is over. What remains is a very useful group of reagents for use in conjunction with other antibodies and with all the conventional skills of histopathology.

We are grateful to Andrew Heryet, Sue Jones, and Helen Turley for excellent technical help, and to Lesley Watts for typing the manuscript.

This work was supported by the Wellcome Trust. KCG is a Wellcome Trust senior research fellow in clinical science and holds the Gilson Scholarship of the Society of Apothecaries of London.

\section{References}

1 Osborn M, Weber K. Intermediate filaments: cell-type-specific markers in differentiation and pathology. Cell 1982;31:303-6.

2 Ramaekers F, Puts J, Kant A, Moesker O, Jap P, Vooijs P. Differential diagnosis of human carcinoma, sarcomas and their metastases using antibodies to intermediate-sized filaments. Eur J Cancer Clin Oncol 1982;18:1251-7.

3 Osborn M, Weber K. Tumour diagnosis by intermediate filament typing: a novel tool for surgical pathology. Lab Invest 1983;48:372-94.

4 Miettinen M, Lehto V-P, Virtanen I. Antibodies to intermediate filament proteins in the diagnosis and classification of human tumors. Ultrastruct Pathol 1984;7:83-107.

5 Gown AM, Vogel AM. Monoclonal antibodies to human intermediate filament proteins. Am J Clin Fathol 1985;84:413-24.

6 Altmannsberger M, Osborn M, Droese M, Weber K, Schauer A. Diagnostic value of intermediate filament antibodies in clinical cytology. Klin Wochenschr 1984;62:114-23.

7 Gould VE. The coexpression of distinct classes of intermediate filaments in human neoplasms. Arch Pathol Lab Med 1985; 109:984-5.

8 Holthofer H, Miettinen A, Paasivuo R, et al. Cellular origin and differentiation of renal carcinomas: a fluorescence microscopic study with kidney-specific antibodies, anti-intermediate filament antibodies, and lectins. Lab Invest 1983;49:317-26.

9 Caselitz J, Becker J, Seifert G, Weber K, Osborn M. Coexpression of keratin and vimentin filaments in adenoid cystic carcinomas of salivary glands. Virchows Arch (Pathol Anat) 1984:403:337-44.

10 Holthofer H, Miettinen A, Lehto V-P, Lehtonen E, Virtanen I. Expression of vimentin and cytokeratin types of intermediate filament proteins in developing and adult human kidneys. Lab Invest 1984;50:552-9.

11 Miettinen M, Franssila KO, Lehto V-P, et al. Expression of intermediate filament proteins in thyroid gland and in thyroid tumors. Lab Invest 1984;50:262-70.

12 Churg A. Immunohistochemical staining for vimentin and keratin in malignant mesothelioma. Am J Surg Pathol 1985;9:360-5.

13 Gatter KC, Dunnill MS, Pulford KAF, Heryet A, Mason DY. 
Human lung tumours: a correlation of antigenic profile with histological type. Histopathology 1985;9:805-23.

14 World Health Organization. The World Health Organization histological typing of lung tumours. Am J Clin Pathol 1982;77:123-36.

15 Viac J, Reano A, Brochier J, Staquet M-J, Thivolet J. Reactivity pattern of a monoclonal antikeratin antibody $(\mathrm{KL1}) . J$ Invest Dermatol 1983;81:351-4.

16 Cordell JL, Falini B, Erber WN, et al. Immunoenzymatic labelling of monoclonal antibodies using immune complexes of alkaline phosphatase and monoclonal anti-alkaline phosphatase (APAAP complexes). J Histochem Cytochem 1984;32:219-29.

17 Gatter KC, Falini B, Mason DY. The use of monoclonal antibodies in histopathological diagnosis. In: Anthony PP, MacSween RNM, eds. Recent advances in histopathology. Vol 12. Edinburgh: Churchill Livingstone, 1984:35-67.

18 Lane EB, Hogan BLM, Kurkinen M, Garrels JI. Coexpression of vimentin and cytokeratins in parietal endoderm cells of early mouse embryo. Nature 1983;303:701-4.

19 Virtanen I, Lehto V-P, Lehtonen E, et al. Expression of intermediate filaments in cultured cells. J Cell Sci 1981;50:45-63.

20 Ramaekers FCS, Haag D, Kant A, Moesker O, Jap PHK, Vooijs GP. Coexpression of keratin- and vimentin-type intermediate filaments in human metastatic carcinoma cells. Proc Natl Acad Sci USA 1983;80:2618-22.

21 Huitfeldt HS, Brandtzaeg P. Various keratin antibodies produce immunohistochemical staining of human myocardium and myometrium. Histochemistry 1985;83:381-9.

22 Vogel AM, Gown AM, Caughlan J, Haas JE, Beckwith JB. Rhabdoid tumors of the kidney contain mesenchymal specific and epithelial specific intermediate filament proteins. $L a b$ Invest 1984;50:232-8.

23 Molenaar WM, Oosterhuis JW, Oosterhuis AM, Ramaekers FCS. Mesenchymal and muscle-specific intermediate filaments (vimentin and desmin) in relation to differentiation in childhood rhabdomyosarcomas. Hum Pathol 1985;16:838-43.

24 Hoetler H, Kerl H, Rauch H-J, et al. New immunocytochemical observations with diagnostic significance in cutaneous neuroendocrine carcinoma. Am J Dermatopathol 1984;6:525-30.

25 van Muijen GNP, Ruiter DJ, Warnaar SO. Intermediate filaments in Merkel cell tumors. Hum Pathol 1985;16:590-5.

26 Miettinen M, Lehto V-P, Dahl D, et al. Varying expression of cytokeratin and neurofilaments in gastrointestinal neuroendocrine tumors. Lab Invest 1985;52:429-36.

27 Miettinen M, Clark R, Lehto V-P, Virtanen I, Damjanov I. Intermediate-filament proteins in parathyroid glands and para- thyroid adenomas. Arch Pathol Lab Med 1985;109:986-9.

28 Lehto V-P, Miettinen M, Virtanen I. A dual expression of cytokeratin and neurofilaments in bronchial carcinoid cells. Int $J$ Cancer 1985;35:421-5.

29 Gabbiani G, Kapanci Y, Barazzone P, Franke WW. Immunochemical identification of intermediate-sized filaments in human neoplastic cells. Am J Pathol 1981;104:206-16.

30 Lehto V-P, Stenman S, Miettinen M, Dahl D, Virtanen I. Expression of a neural type of intermediate filament as a distinguishing feature between oat cell carcinoma and other lung cancers. Am J Pathol 1983;110:113-8.

31 Lehto V-P, Miettinen M, Dahl D, Virtanen I. Bronchial carcinoid cells contain neural-type intermediate filaments. Cancer 1984;54:624-8.

32 van Muijen GNP, Ruiter DJ, van Leeuwen C, Prins FA, Rietsema K, Warnaar SO. Cytokeratin and neurofilament in lung carcinomas. Am J Pathol 1984;116:363-9.

33 Blobel GA, Gould VE, Moll R, et al. Coexpression of neuroendocrine markers and epithelial cytoskeletal proteins in bronchopulmonary neuroendocrine neoplasms. Lab Invest 1985;52:39-51.

34 Broers J, Huysmans A, Moesker O, Vooijs P, Ramaekers F, Wagenaar S. Small cell lung cancers contain intermediate filaments of the cytokeratin type. Lab Invest 1985;52:113.

35 Baumal R, Kahn HJ, Bailey D, Phillips MJ, Hanna W. The value of immunohistochemistry in increasing diagnostic precision of undifferentiated tumours by the surgical pathologist. Histochem $J$ 1984;16:1061-78.

36 Lauder I, Holland D, Mason DY, Gowland G, Cunliffe WJ. Identification of large cell undifferentiated tumours in lymph nodes using leucocyte common and keratin antibodies. Histopathology 1984;8:259-72.

37 Gatter KC, Alcock C, Heryet A, Mason DY. Clinical importance of analysing malignant tumours of uncertain origin with immunohistological techniques. Lancet 1985;i:1302-5.

38 Ghósh AK, Erber WN, Hatton CSR, et al. Detection of meta static tumour cells in routine bone marrow smears by immuno alkaline phosphatase labelling with monoclonal antibodies. $B \vec{P}$ J Haematol 1985;61:21-30.

39 Wells CA, Heryet A, Brochier J, Gatter KC, Mason DY. The immunocytochemical detection of axillary micrometastases in breast cancer. Br J Cancer 1984;50:193-7.

Requests for reprints to: Dr KC Gatter, Nuffield Department of Pathology, John Radcliffe Hospital, Oxford OX3 9DU, England. 